\title{
Senior High School Students' Character Traits, Word Problem Analysis Skills and Academic Achievement in Mathematics
}

\author{
V. E. Tamban, R. A. Lagarto, C. E. Malabayabas
}

\section{ABSTRACT}

This study was conducted with the purpose of finding out whether the character traits significantly influenced the problem solving analysis skills and academic achievement in mathematics of Senior High School students. It was a descriptive - survey and correlational study which involved 75 students, total enumeration was utilized. Questionnaires were availed to gather the data needed. Frequency count, percentage, weighted mean and chi-square (x2) were employed to arrive at precise and valid results. The findings of the study revealed that character traits of students were varied, however, majority were satisfactory. They practiced acceptable and healthy behaviours in relating with others. Majority of the pupils were above average in their level of problem analysis skills in involving problems in mathematics. Most of them had achieved an academic achievement of satisfactory. They had mastered the skills as per required of them to learn in Mathematics. It was found out that character traits significantly influenced the problem solving analysis skills and academic achievement in mathematics.

Keywords: Academic Performance, Character Traits, Word Problem Analysis Skills.
Published Online: November 16, 2021

ISSN: 2736-5522

DOI: 10.24018 / ejsocial.2021.1.6.158

V. E. Tambian*

College of Teacher Education, Laguna State Polytechnic University, , Los Baños, Laguna, Region IVA, Philippines.

victoria.tamban@1spu.edu.ph

R. A. Lagarto

Saripinang National High School, Bai Saripinang, Bagumbayan, Sultan Kudarat, Region XII, 9810 Philippines.

rickyaprong@gmail.com

C. E. Malabayabas

College of Teacher Education, Laguna State Polytechnic University, Los Baños, Laguna, Region IVA, Philippines.

cristina.malabayabas@1spu.edu.ph

*Corresponding Author

\section{INTRODUCTION}

Solving mathematical problems needs patience, intelligence and understanding. These are character traits one should possess to be successful not only in solving mathematical problems but equally important in living a peaceful life. Thus, mathematics teachers should try their best to develop the mathematical skill processes to be confident that more or less they could be helpful to their pupils' future life

Teachers in school are believed to be an important influence on learners (D'assico \& Cardar, 2003). Their teaching contributes to the development of academic confidence and success. Further, Parkes, Guarino \& Smith (2012) emphasized that both students beliefs in the ability to learn academic subjects and teachers' ability to motivate and encourage learning affect character traits developed by their students and academic performance. It is in this idea that this study was conducted to find out whether character traits possessed by students as developed by their teachers influenced also their abilities to solve mathematical problems.

This study is based on the concept that character traits and word analysis skills could influence academic achievement. This view is rooted with the belief that the extent to which proper acceptable habits, traits and skills are formed is contributory to the success of life, especially in one's academic growth. This is in keeping with the Thorndike's connectivism theory (1874-1949), where he did not limit himself to the association between the stimulus and response. He put emphasis on the responses of the organism. Connections mainly occur through learning by selecting and connecting. This theory of connectivism made Thorndike formulate laws of learning, where the law of effect was found to be appropriate in explaining the concept formulated.

According to the law of effect, when the organism's response is accompanied or followed by satisfactory state, the strength of the connection is increased. When an annoying state accompanies or follows the response, the strength of the connection is decreased. In this study, it means that the more acceptable are the character traits of the students and the more satisfactory are their problem analysis skills, it follows that they would have higher academic achievement. The poorer are the state of their character traits and analysis problem solving skills; it would be expected that it will be accompanied by poorer achievement in school academics.

Further, Houston (2013) shared that the more learners are motivated to learn if they experience something 
pleasant to their feelings. In other words, as what observation and empirical studies tell us, learners tend to learn more effectively and retain the learning longer, if he/she experience pleasant consequences. That is, as applied in the study, if favorable character traits and very satisfactory problem solving analysis skills made the students feels easy to learn Mathematics, the more they will attain higher achievement because they have pleasant experiences.

In this study, the character traits and problem analysis skills served as the independent variable. They are the stimulus that would motivate to make the students feel learning Mathematics easy, thus, academic achievement in Mathematics will be increased. The more pleasant experience character traits and problem analysis skills will be gained in learning Mathematics; the higher would be the achievement in this discipline.

Independent Variable Dependent Variable

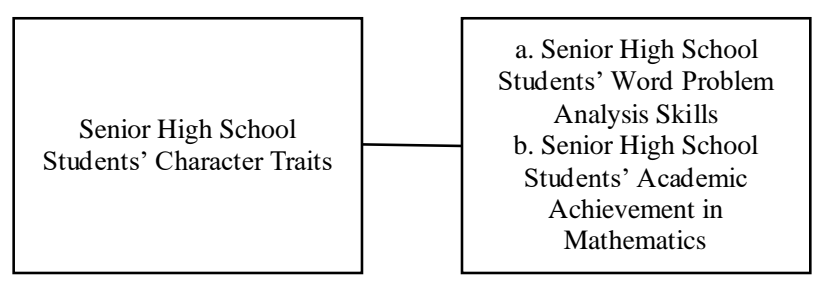

Fig 1. The research paradigm

This study was conducted to determine whether there were relationships among the character traits, word problem analysis skills and academic achievement in Mathematics among Senior High school students of College of Teacher Education, Laguna State Polytechnic University, Los Baños Campus during the School Year 2020-2021. Specifically, it sought answers to the following questions:

1. What are the levels of the character traits do the students possess?

2. What are the levels of their problem analysis skills in Mathematics?

3. What are the levels of their academic achievement in Mathematics?

Are there significant relationship existing between their levels of character traits and levels of their problem analysis skills in Mathematics; and character traits and levels of their academic achievement in Mathematics?

This investigation was limited to determine whether there were relationships among the character traits, word problem analysis skills and academic achievement in Mathematics among Senior high school students of College of Teacher Education Los Baños Campus, during the School Year 2020-2021. Furthermore, it should determine what implications to Mathematics enhancement program should be drawn from the results of the study.

\section{Methodology}

The descriptive-correlational method of research will be applied in this study. This will be the most appropriate method or research because the main intention of this study is to find out whether there will be a significant relationship among the character traits, word problem analysis skills and academic achievement in Mathematics among public secondary school students. It will be supported by PalerCalmorin and Calmorin (2010) that if the main intention of the study was to make a survey to determine the existing status of the phenomena investigated, descriptive- survey could be the most suitable research design especially if according to Sevilla et. al. (2012), the study was not concerned of the causes why the existing situations happened.

As further emphasized by Paler- Calmorin and Calmorin (2010), this kind of research design was appropriate if the intention was to determine how a variable influences the other wherein relationships described whether the relationship was perfect, very high, high, moderate, slight or negligible. Hence, if relationship exists, the influenced of the other variable to another would be determined.

The 75 respondents of the study came from the senior high school students enrolled in College of Teacher Education, Los Baños Campus, Los Baños, Laguna. Inasmuch as the population is small, total enumeration was used. No sampling technique should be applied as suggested by Paler-Calmorin and Calmorin (2010).

There were three instruments which were used in this study. These were the Academic achievement in Mathematics, Character Traits and Word Problem Analysis.

Academic Achievement in Mathematics. This was an official document used by the DepEd in gathering the average grades of the secondary students by grading period. The researcher prepared a copy of the grading sheet to collect the grades in Mathematics during the first and second grading periods of the present school year. The average grade of the students from first grading and second grading was taken to represent the other variable of the study which was the academic achievement in Mathematics. The grades were described as Excellent/Very Satisfactory (86 and above); Satisfactory (80 to 85); Fair (75 to 79) and Needs Improvement (74 and below). 
Character Traits Questionnaire. This instrument was designed to determine the qualities possessed by the secondary school students as manifested like being intelligent; decisiveness, self-confidence, initiative and the like. This trait was evaluated and scored above satisfactory ( 8 above); satisfactory (5-6) below satisfactory (4 below).

Word Problem Analysis skills. This is instrument was designed determine the word problem analysis skills of the secondary students. This instrument was composed of 50 items where in the students are going to analyze the story problem; what are the given data in the story problem; what Mathematical operation to use and how to apply the appropriate computation to arrive to the correct answer. The scores of the students was categorized into three (3) levels namely above average, average and below average.

There were steps followed in conducting and validating the research instrument which was the Academic Achievement in Mathematics. It started with content validation whereby documentary analysis of the teachers' manual and students' textbook were done considering the topics or subject matter content to be covered during the duration of the study. In this step, it was found out that there were 7 objectives covered within the period of the study and it was taught within the 26-day period. This was actually during the first and second grading period. Based on the survey of the topics to be covered, a table of specification was then developed and prepared to be consulted to the experts in teaching the subjects. The experts considered here were the mathematics teachers who had been teaching the subject for more than 5 years. Then, it was referred to the adviser who was also an expert in the field of Mathematics.

During the construction of the items, the suggestions of the panel that at least 100 percent allowance of the items were followed. This was done in order to ensure that there were enough items retained after the item analysis or first trial run.

These 50 items were then prepared as the first manuscript of the instrument. It was submitted for face validation. To reinforce the face validation of the instrument this was submitted for item inspection to three Mathematics teachers. This was done to ensure that the items were well presented and that the items were relevant, suitable and appropriate to the objectives as presented in the Table of Specification. Inter-judge consistency was followed wherein, at least two (2) out of the three judges or evaluators of the items had agreed with the items as with reference of the criteria set.

The sample of manuscript validation of the items inspected. All items which were accepted became the items of the next manuscript prepared. It was prepared to be tried out to a sample comparable to the target population. The try out was done to the other group of students who were not involved in the study. Then it was scored ready for item analysis. This was done because according to Ferguson (1989) as cited by Fraenkel and Wallen (2007), high validity and reliability can be built into the instrument in advance through item analysis.

The technique of item analysis used in this study was U-L Index Method. This technique was advanced by John Stocklein (1957) as cited by Calmorin and Calmorin (2007) to be a technique which is appropriate for test whose criterion was measured along a continuous scale like achievement test scores. The researcher followed the steps to be employed in using this technique and the results contained the two summary of the item analysis showing the item number; the frequency percentage/proportion of the upper 27 percent and lower 27 percent where the difficulty Index (df) and Discrimination Index (Ds) were calculated.

The calculated indices served as the deciding factor whether to retain or discard an item. Items with difficulty indices within .20 to .80 and discrimination indices within .30 to .80 were retained. The ChungTee-Fan Item Analysis Table was used to obtain the discrimination indices of the interpreted using Ebel's "rule of thumb" (Stanley \& Hopkins, 1972).

Below is the Chung-Tee-Fan Item Analysis:

TABLE I: CHUNG-TEE-FAN ITEM ANALYSIS

\begin{tabular}{cc}
\hline \hline Index Discrimination & Evaluation \\
\hline 0.40 and up & $\begin{array}{c}\text { Very good item } \\
\text { Reasonably good item } \\
\text { but possible subject to } \\
\text { improvement }\end{array}$ \\
$0.30-0.29$ & $\begin{array}{c}\text { Poor item, to be rejected, } \\
\text { improve or revised }\end{array}$ \\
\hline \hline
\end{tabular}

As the result of the item analysis, there were thirty (30) items which were, improved and accepted; the researcher prepared the final manuscript for the second run or final test administration. This was the process whereby the test was evaluated for its test reliability.

In this study, the internal-consistency method particularly the split half procedure was availed to estimate its reliability. The test in this method was administered once, but the test items were divided into two halves. The scores obtained in two halves were correlated. The result was the reliability coefficient for a half test. In this study, the reliability of the whole test was 0.92 . the " $r$ " value obtained was very high, hence the test was valid. Inasmuch as the test was found valid and reliable, the final manuscript of the instrument was produced in enough copies to the number of subjects of the study considered in this investigation. 
Procedure in the Administration of the Instrument. After the test was found valid and reliable, the final manuscript was produced in enough copies ready to be administered to the final respondents. To ensure the consistency of giving instructions, the researcher personally administered the test. The subjects of the study were assured that whatever were the scores they may have obtained, this may not affect their classroom performance in Mathematics.

Procedure in Tabulating the Results. After the test was administered, they were gathered and scored. Then, the scores were organized ready to be treated with appropriate statistical tools as asked in the subproblems.

Statistics were used to interpret and analyzed data gathered.

In subproblem numbers 1, 2 and 3 the statistical tools used were frequency count and percentage with the formula: $\%=\mathrm{f} / \mathrm{N} \times 100$ where $\%$ stands for percentage; $\mathrm{f}$ for frequency and $\mathrm{N}$ is for number of cases.

For subproblem number 4, chi-square (X2) test was used to determine relationships among the character traits, word problem analysis skills and academic achievement in Mathematics, with the formula: X2 $=(\mathrm{O}-$ E) $2 / \mathrm{E}$, where $\mathrm{X} 2$ is the Chi-square Test, $\mathrm{O}$ is the observed frequency and $\mathrm{E}$ is the expected frequency.

\section{RESUlTS AND DiscusSIONS}

Table II presents the data gathered about the levels of the character traits possessed by the 75 Senior High School student respondents. Frequency counts and percentage are the statistical tools employed.

\begin{tabular}{ccc} 
TABLE II: LEVELS OF CHARACTER TRAITS AMONG GRADE & 10 STUDENTS N=20 \\
\hline \hline Level of character traits & Frequency & Percentge \\
\hline Above satisfactory & 29 & 38 \\
Satisfactory & 38 & 51 \\
Below satisfactory & 8 & 11 \\
\hline Total & 75 & 100 \\
\hline \hline
\end{tabular}

Character traits are categorized into three (3) levels. These are Above Satisfactory, Satisfactory and Below Satisfactory. Data show that 29 or 38 percent possessed above satisfactory level of character traits. These indicate that the scores they obtained were 8 and above. It means that this group of students possessed character traits greater than what are expected of them. As explained by Esmer (2007) they have personal qualities that manifest their above average intelligence, decisiveness, self-confidence initiative and the like. As supported by Payne, (2007) they are students who possessed very good personality with character traits highly acceptable to their peers, teachers and parents.

Further, there are 38 or 51 percent of the senior high school students respondents who belonged to satisfactory level of character traits. It indicates that their scores are within the values of 5 to 6 . This means that they had possessed character traits in an average level as expected of them. As explained by Hurlock (2010), they are people whose personal qualities meet the required standard as expected of them by people around them. They have pleasant personality because of their patience, understanding and warmth. They don't find difficulty in adjusting to people of varied personalities.

Lastly, eight (8) or 11 percent possessed below satisfactory level of character traits. As emphasized by Lester (2007), they need improvement to appear acceptable to majority of the people in their school environment. They needed to be more decisive in making decisions as well as improve their self-confidence.

Generally, it indicate that majority of them have Satisfactory level of character traits, they possess personal quality laden of values that meet the standard requirement expected of them at their age level. They manifest character of a person worthy of respect and acceptance.

Table III has the data presenting the levels of problem solving analysis skills in Mathematics among the Senior High School students.

\begin{tabular}{ccc} 
TABLE III: LEVEL OF PROBLEM SOLVING ANAL YSIS & SKILLS OF GRADE & 10 STUDENTS IN MATHEMATICS \\
\hline \hline Level of problem analysis skill & Frequency & Percentage \\
\hline $\begin{array}{c}\text { Above average } \\
(15 \& \text { above average }) \\
\begin{array}{c}\text { Average } \\
\text { (6 to 14 Scores })\end{array}\end{array}$ & 54 & 72 \\
\hline Total & 21 & 28 \\
\hline \hline
\end{tabular}

It is indicated in the table that of the 75 students involved in the study, 54 or 72 percent belonged to above average level. This result recorded the scores of $15 \&$ above on the achievement test given about analyzing word problem in Mathematics. It means that this group of students obtained mastery about the necessary skills expected of them in solving Mathematical problems. They are equipped with the necessary mathematical concepts and ideas as well as analysis skills in solving Mathematical problems. As Ebels (2010), described, they are learners who are prepared to move on to the higher learning skills. They 
manifested the ability to solve more complicated problems in Mathematics.

Moreover, there are 21 or 28 percent of the 75 students who obtained average and Below level of problem solving analysis skills. They are students whose scores were 14 and below. They moderately master the necessary knowledge, skills and values expected of them to master as required in their grade level. Ebel (2006) described them to be learners who need more coaching because they were not able to master the mathematical skills they should learn as expected of them. As supported by Ruly (2007), they are students who needed to undergo remediation or help in order for them to reach the mastery level expected of them.

In summary, the levels of the students respondents in analyzing word problems were above average. Most of them meet the necessary knowledge and skills as per required of them. It is also a gentle hint that mentors should take good care of their everyday lessons not only to maintain their skills but to go beyond to obtain excellence. But then, as Cruickshank, et al (2015) reminded, teachers should be creative and more adaptable, that while helping those above average students they should not neglect the group that fall behind. Teachers should try to maintain balance so that as the best students go on to excellence so are the poor ones moving towards what are expected of them to master on the grade level they are presently in. After all, teachers teach word problem analysis skills so that students would understand problems for them to analyze, what are they about, and to arrive on the appropriate computation to arrive to reach the correct answer.

Table IV presents the data gathered about this subtopic by gathering the academic grades of the student respondents. The levels are categorized into Outstanding, Very Satisfactory, Satisfactory, Fair and Needs Improvement. Frequency counts and percentage are utilized to treat the data gathered.

TABLE IV: LEVELS OF ACADEMIC ACHIEVEMENT IN MATHEMATICS

\begin{tabular}{|c|c|c|}
\hline Level of Academic Achievement & Frequency & Percentage \\
\hline $\begin{array}{l}\text { Excellent/Outstanding } \\
\text { (91 \& above) }\end{array}$ & 52 & 69 \\
\hline $\begin{array}{c}\text { Very Satisfactory } \\
(86-90)\end{array}$ & 20 & 27 \\
\hline $\begin{array}{c}\text { Satisfactory } \\
(75-79)\end{array}$ & 2 & 3 \\
\hline $\begin{array}{c}\text { Fair } \\
(75-79)\end{array}$ & 1 & 1 \\
\hline $\begin{array}{l}\text { Need Improvement } \\
\quad(74 \text { \& Below })\end{array}$ & 0 & 0 \\
\hline Total & 75 & 100 \\
\hline
\end{tabular}

Data revealed that fifty two (52) or sixty nine (69) percent obtained a grade of 91 and above describing him to be on Outstanding academic achievement in Mathematics. Ebel (2010) describes him to have mastered the knowledge and skills taught in their Mathematics class within that period of time. He needs no coaching, and could even work in advance Mathematics lessons required in the class.

Records also show that twenty (20) or 27 percent obtained grades between 86 to 90 . They are described to have obtained Very Satisfactory achievement level. It means that they are above average on their learnings related to the topics discussed in Mathematics within the period of time. They had learned the lessons more than what are expected of them.

Further, 2 or 3 percent of the students obtained academic achievement level of Satisfactory. This indicates what they had mastered the learning skills as per required.

It also means that they need to work an extra mile to obtain the highest grade toward excellence. As Ebel (2010) describe they just meet the requirements. They mastered only skills on the average level.

Furthermore, there are 1 or 1 percent whose academic achievement in Mathematics was on Fair level. It indicates that their grades were between 75 to 79 . This achievement denotes more needed work to obtain better grades. These children did not master the required Mathematical skills expected of them. They fall short to meet the required expected achievement about the skills they should master.

However, it was noted that nobody of the respondents were found to belong to Needs Improvement Level. It means that nobody failed in Mathematics.

TABLE V: DATA SHOWING SignifiCANT RELATIONSHIP AMONG LEVELS OF CHARACTER TRAITS, PROBLEM SOLVING ANALYSIS SKILLS AND ACADEMIC ACHIEVEMENT IN MATHEMATICS

\begin{tabular}{ccccc}
\hline \hline Variables & Df & Tabular X $X^{2} .05$ & Obtained X $^{2}$ & Decision $\{.05$ \\
\hline Character Traits & & & & $13.42>5.99$ \\
VS & & & & Reject $\mathrm{H}_{\mathrm{o}}$ \\
Word Problem Analysis & 2 & 5.99 & 13.42 & Significant \\
$\quad$ Skills & & & & $24.112>9.488$ \\
$\begin{array}{c}\text { Character Traits } \\
\text { VS }\end{array}$ & & & & Reject $\mathrm{H}_{\mathrm{o}}$ \\
$\begin{array}{c}\text { Academic Achievement in } \\
\text { Mathematics }\end{array}$ & 4 & 9.488 & 24.112 & Significant \\
\hline \hline
\end{tabular}


Table $\mathrm{V}$ has the data concerning the presentation whether there is a significant relationship among the students' level of character traits, problem solving analysis skills and their academic achievement in Mathematics. Chi-square (X2) test was employed to treat the data gathered. This was constructed at .05 level of confidence.

It is noted in the results that with the variables concerning character traits and problem-solving analysis skills, the obtained chi-square (X2) test value was 13.42. Tested at .05 level, with df equals 2 , the required $\mathrm{X} 2$ tabular value is 5.99. The computed chi-square (X2) test value was 13.42. This was greater than 5.99, thus, it means that these two variables are significantly related with each other. It indicates that the better the character traits of the students, the higher would be their problem solving analysis skills. This is true because as Alkin (2007) emphasized, to analyze and solve a problem, it needs patience, understanding and intelligence. Mathematical problems needed individuals who have patience to understand what were asked about as well as intelligence to compute correctly to arrive to the required answer.

Furthermore, with regards to whether there exist a significant relationship between character traits and academic X2 value obtained is 24.112 . At .05 level with df equals 4 , the required value of significance is 9.488. The computed X2 value of 24.172 is greater than the X2 tabular required value, thus the null hypothesis was rejected. It simply means that there is a significant relationship between these two variables. The better the character traits possess by the students, the higher would be their academic achievement in Mathematics. As what Bucu (2008) has cited school achievement regardless of what academic subjects they are, it needed patience, understanding and intelligence to achieve high. These character traits are contribute to one's success. In fact as Gregorio (2009) has added, if an individual is warm he knows how to listen and be quit. Being quit they became modest, open o suggestion and honest. These character traits as he emphasized add more confidence to achieve higher in any endeavour in life.

Taken together data show that there was a significant relationship between character traits and problem solving analysis skill. It also proved that there is a significant relationship between character traits and academic achievement in Mathematics. There is a significant correlations existing among these three variables. They are affecting one another.

\section{CONCLUSIONS AND ReCOMMEDATIONS}

There was a significant relationship that existed between character traits and problem solving analysis skills of the Grade 10 students. This was also true between their character traits and academic achievement in mathematics. There were significant relationships among these variables. The better the character traits, the higher would be the problem analysis skills and academic achievement in mathematics of the students.

Based on the results, it is recommended that school administrators could use the results as a reference what issues to discuss during teachers' in-service trainings to help improve the skills of the teachers in employing different strategies in teaching solving word problems; mathematics teachers are encouraged to use the data gathered to serve as their basis in improving their techniques and strategies in teaching the learning area; students of Mathematics would be inspired to learn the lessons motivated by the character traits demonstrated like patience and good preparation of their teachers teaching this learning area, and researchers could use the related literatures and studies to serve as their reference if ever they wanted to undergo related studies focused in this subject area.

\section{ACKNOWLEDGMENT}

The authors would like to humbly thank the President of Laguna State Polytechnic University, Dr. Mario R. Briones, the Vice President of RDE, Dr. Robert C. Agatep, the Director of R \&D, Christian Paul P. Dela Cruz, and Associate Dean Dr. Karen A. Manaig of College of Teacher Education for their support for the product of this research study.

\section{CONFLICT OF INTEREST}

Authors declare that they do not have any conflict of interest.

\section{REFERENCES}

Alkin, K. (2007). Cognitive strategy instruction and mathematical problem-solving performance of students with learning disabilities. Learning Disabilities Re search \& Practice, 29, 251-261.

Bucu, A. (2008). Social foundations of thought and action: A social cognitive theory. Englewood Cliffs, NJ: Prentice Hall.

Bunch, P. (2008). More Than 1-2-3- The Real Basic of Mathematics. Washington DC: National Association for the Education of Young Children.

Calmorin, P. \& Calmorin, L. (2010) Methods of Research. Quezon City: Philippines. 
European Journal of Humanities and Social Sciences www.ej-social.org

Chisko, L. (2007). Teachers' beliefs and practices related to mathematics instruction. Teaching and Teacher Education, 17(2), 213226.

Doyal, M. \& Patrickk, K, (2007). Foundations for success: The final report of the National Mathematics Advisory Panel. Washington, DC: U.S. Department of Education.

Ebel, M. (2010). The role of tutoring in problem-solving. Journal of Child Psychology and Psychiatry, 17, 89- 100.

Ebel, T. (2007). Academic self-handicapping and performance goals: A further examination. Contemporary Educational Psychology,

26, 61-75.

Ellerton, C. \& Clarkson, M. (2007). Is math a gift? Belthat put females at risk. In S. J. Ceci \& W. Williams (Eds.), Why aren't more women in science? Top researchers debate the evidence (pp. 47-55). Washington, DC: American Psychological Association.

Esmer, M. (2007). The effects of cognitive and metacognitive strategy instruction on mathematical problem solving of middle school students with learning disabilities. Journal of Learning Disabilities, 25, 230-248.

Ferguson, H. (2009). The structure of classroom discourse. In T. van Dijk (Ed.), Handbook of discourse analysis (Vol. 3, pp. 119131). London: Academic Press.

Fuson, K., Caroll, M, Landis, M. (Eds.). (2007). Scaffolding student learning: Instructional approaches and issues. Cambridge, MA: Brookline Books.

Gambrell, J. M., Kapinus, K. E., Koskinen, A. J. (2008). Rethinking achievement goals: When are they adaptive for college students and why? Educational Psychologist, 33, 1-21.

Gregorio, R. (2009). Learning styles: Concepts and evidence. Psychological Science in the Public Interest, 9(3), 105-119.

Huer, P. (2007). Word Problem Analysis Skills. Upper Saddle River, NJ: Pearson

Kaur A. J. \& Yup, L. (2007). Development of metacognitive skills of prediction and evaluation in children with or without math disability. Learning Disabilities Research \& Practice, 21(2), 77-88.

Kaur, J. (2007). Problem Solving Styles: Developing appreciation for particular learning domains and activities. Educational Psychologist, 34, 75-85.

Lardizabal, F. (2009). Self-efficacy beliefs in academic settings. Review of Educational Research, 66(4), 543-578.

Leblanc, D., Weber, J., Russel, N., (2008). Encouraging girls in math and science: IES practice guide (NCER 2007-2003). Washington, DC: Institute of Educational Sciences, U.S. Department of Education. Available: http://ies.ed.gov/ncee/wwc/pdf/practiceguides/20072003.pdf

Lester, L. \& Kehle, P. (2009). Problem Solving Skills. Hillside, NJ: Erlalbum.

Lester, R. (2007). Character Traits: Teaching mind in society: Teaching,schooling, and literature discourse. In L. C. Moll (Ed.), Vygotsky and education: Instructional implications and applications of sociohistorical psychology (pp. 175-205). Cambridge, England: Cambridge University Press.

Marinas, M. V., \& Clemens, C. L. (2007). Effort: The double-edged sword in school achievement. Journal of Educational Psychology, $71,169-182$.

Matlin, C. (2007). Female teachers' math anxiety affects girls' math achievement. Proceedings of the National Academy of Sciences, USA, 107(5), 1060-1063.

McGin, L. \& Boote, S. (2007). The relational zone: The role of caring relationships in the co-construction of mind. American Educational Research Journal, 36, 647-673.

Newman, C. (2007). The impact of goal orientation on self-regulation and performance among college students. British Journal of Educational Psychology, 65, 317-329.

Payne, A. T. (2007). Developments and its discontents: The differentiation of the concept of ability. In J. G. Nicholls (Ed.), Advances in motivation and achievement (pp. 185-218). Greenwich, CT: JAI Press.

Phares, L. (2008). Effects of task and ego achievement goals on help-seeking behaviors and attitudes. Journal of Educational Psychology, 87, 261-271.

Polya, R. (2009). Determinants of help seeking: Relations between perceived reasons for classroom help-avoidance and help-seeking behaviors in an experimental context. Journal of Educational Psychology, 90, 630-643.

Richardson, C. (2009). Teachers' communication of goal orientations in four fifth-grade classrooms. Elementary School Journal, 102, $35-38$.

Ruly, T. (2007). Scaffolding techniques of expert human tutors. In K. Hogan \& M. Pressley (Eds.), Scaffolding student learning: Instructional approaches and issues (pp. 108-144). Cambridge, MA: Brookline Books.

Schoenfeld, C. M. (2007). Problem Solving Styles. Boston: Allyn \& Bacon.

Sirion, P. (2007). The intersection between self-concept and values: Links between beliefs and choices in high school. New Directions for Child and Adolescent Development, 110, 31-47.

Skypeck, D. H. (1980). Girls Need Mathematics Too. Arithmetic Teacher, 27, 5-7.

Sulla, T. (2008). Effects of mathematical word problem solving by students at risk or with mild disabilities. The Journal of Educational Research, 91, 345-355. 


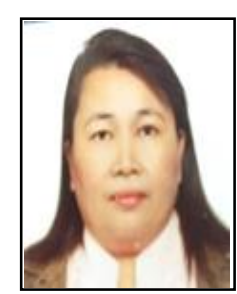

Dr. Victoria E. Tamban is the concurrent Innovation Technology Support Office (ITSO) Manager of LSPU System, She is also one of the professor in Graduate Studies and Applied Research (GSAR) under College of Teacher Education (CTE) of Laguna State Polytechnic University (LSPU) Los Baños Campus hand ling Advanced Statistics, major subjects in Mathematics, and some of professional subjects and General subject, "Understanding the Self." She finished her Master of Arts in Teaching major in Mathematics at the same university in 2014. She already finished her doctorate degree in Educational Management at LSPU-LBC. She presented various researches in local and international conferences and published in refereed journals. She is also the main author of Module in Understanding the Self, A Text/Workbook in Methods of Research, Module in Methods of Research, and Module in Probability. She is also involved in Christian Ministry and a Chaplain Officer in Pastors' Auxiliary Chaplains Association International Inc. (PACAII).

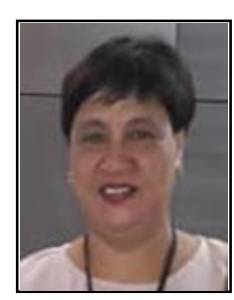

Prof. Cristina E. Malabayabas is the concurrent Senior High School Coordinator. She was a former BEEd Coordinator under the College of Teacher Education since 2006 to 2021. She is a graduate of Bachelor of Secondary Education Major in Filipino and earned units in Bachelor of Elementary Education at LCBA. She finished her Master of Arts in Education major in Filipino at PCHS and she is teaching Professional subjects, major subjects in Filipino and in BEEd. She is also teaching Understanding the Self.

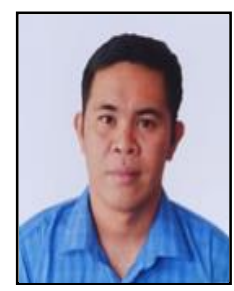

Mr. Ricky A. Lagarto is presently employed as Teacher II at DepEd-Bai Saripinang National High School in the Division of Sultan Kudarat. He is handling Mathematics subjects in Senior High School since it was implemented in the Philippines. He graduated his Master of Arts in Education major in Mathematics at Southern Philippine Academy College Inc. In the year 2015. He earned units for his Doctor of Education major in Educational Management at the University of Southeastern Philippines at Davao City. He was able to published one of his educational researches in the international journals. 